\title{
Protection Efforts of Coral Reefs Ecosystem from Anthropogenic Threats at Karimunjawa National Park, Indonesia
}

\author{
Kusuma Dewi ${ }^{1 *}$, Sunarsih ${ }^{2}$, and Lita Tyesta A.L. Wardhani ${ }^{3}$ \\ ${ }^{1}$ Master Program of Environmental Science, School of Postgraduate Studies, Universitas Diponegoro, \\ Semarang - Indonesia \\ ${ }^{2}$ Department of Mathematics, Faculty of Science and Mathematics, Universitas Diponegoro, \\ Semarang - Indonesia \\ ${ }^{3}$ Faculty of Law, Universitas Diponegoro, Semarang - Indonesia
}

\begin{abstract}
The coral reef area at Karimunjawa National Park is decreasing over time. There are two factors causing damage to coral reefs, namely natural factors and anthropogenic factors. The purpose of this study was to determine the anthropogenic threats that cause damage to coral reefs at Karimunjawa National Park and any protection efforts to maintain sustainability. The data of this research were obtained from interviews and literature reviews. The study results show that tourist activities, fishing activities caused damages to coral reefs due to anthropogenic factors and barge rests in conservation areas. Karimunjawa National Park managers carried out law enforcement to protect the coral reefs. Legal enforcement activities are carried out against fishers who are caught using cantrang nets and potassium. Ten fishermen have been convicted of illegal fishing using the types of equipment. Barge activities that damage coral reefs are also subjected to legal action. There are 8 cases of vessel grounding that have been resolved by paying compensation. Law enforcement activities are a form of responsibility for the damage to coral reefs that have been caused. Law enforcement is an effort to protect coral reef ecosystems in addition to socialization and patrolling.
\end{abstract}

\section{Introduction}

Indonesia Indonesia is known to have abundant biodiversity. This biodiversity must be protected so that no extinction or damage occurs. For that reason, a form of protection and preservation of such biodiversity is needed in a National Park conservation area. Based on Article 1 Number 14 of Law No. 5 of 1990 concerning the Conservation of Living Natural Resources and their Ecosystems, National Park is defined as an area of native ecosystems that are preserved. Their management is carried out through a zoning system aimed at education, science, research, and support for cultivation, recreation, and tourism [1].

* Corresponding author: dewi.bpn.jateng@gmail.com 
Apart from being a conservation area, a national park can also be used for various activities: first, research activities and scientific development, one of which is a research and experimentation site. Second, activities to raise awareness of national park conservation and education, for example, is ecotourism, a place for fieldwork. Third, the use of water, hydropower, wind, and heat, for example, is the use of water in manufacturing bottled water in industry, small-scale hydropower plants. Fourth, activities of utilizing plants and animals, for example, orchids and shark breeding. Fifth, utilization activities from germplasm, for example, seed gardens. Sixth, traditional utilization activities include traditional fish farming, extraction activities other than wood from forest products, and so on [2].

One of the National Parks in Indonesia that has an abundance of biodiversity is the Karimunjawa National Park. The Karimunjawa National Park area has twenty-two islands consisting of Karimunjawa Island and Kemujan Island as the largest islands, while the others are small islands of twenty. Besides islands, the Karimunjawa National Park area has five types of ecosystems: coral reef ecosystems, lowland tropical rainforest ecosystems, coastal forest ecosystems, seagrass and seaweed ecosystems, and mangrove forest ecosystems [3].

The coral reef is a collection of corals and/ or a coral ecosystem built mainly by limestoneproducing marine biota and marine biota, and other biotas that live freely in the surrounding waters [4]. Coral reef ecosystems are a collection of limestone (CaCO3) formations that live in the bottom of the waters, which are strong enough to withstand the waves of seawater. Coral reefs have many functions and benefits, including protecting the coastal ecosystem, as a tourist attraction, a source of medicine, a home for many types of living things in the sea, as a source of education, and so on [5]. Coral reef ecosystems have an essential function that must be preserved, not damaged or dead. The area of coral reefs in Karimunjawa has decreased year after year. Through Landsat images in 1996, the Karimunjawa archipelago has a coral reef area of $7.074 .800 \mathrm{~m} 2$; in 2002, the area of coral reefs was $6.674 .500 \mathrm{~m} 2$, and in 2016 the area of coral reefs was $5.946 .800 \mathrm{~m} 2$. The decline of coral reefs in the Karimunjawa archipelago from 1996 to 2016 was $15,94 \%$, or the same as an area of $1.128 .000 \mathrm{~m} 2$ from 7.074.800 $\mathrm{m} 2$ [6].

The leading causes of damage to coral reef ecosystems are natural factors and anthropogenic factors or human activities. Damage to coral reefs is caused by natural factors, for example, changes in seawater temperature, typhoons, global climate change, earthquakes, volcanic eruptions, predators, and diseases. The impact of damage to coral reef ecosystems caused by anthropogenic factors is more chronic and is not temporary. The damage to coral reefs caused by anthropogenic factors can be direct or indirect. Examples are fishery activities, ornamental fish fishing, fish consumption, shellfish and shrimp harvesting with explosives, toxic chemicals, electricity, fishing gear that is not environmentally friendly such as potassium, overfishing, and irregular harvesting [7]. Karimunjawa National Park recently ranked in the top third of threatened marine parks in Indonesia, with its reefs scoring highly due to local pressures (anthropogenic threats) [8].

Based on this description, the purpose of this study is to determine the anthropogenic threats causing damage to coral reefs in Karimunjawa National Park and the protection efforts of coral reefs to maintain their sustainability.

\section{Research method}

This research is a descriptive study using primary data and secondary data. The purposive sampling method selected primary data from in-depth interviews with three key informants from the Karimunjawa National Park Office informants. Informants are government employees in Karimunjawa National Park Agency and provide information about Karimunjawa National Park management. Secondary data obtained from the literature review related to the topic of discussion. Materials were obtained from Science Direct, Springer, and 
Google Scholar from 2013-2021 by searching for damage to Karimunjawa's coral reefs and efforts to protect coral reefs, then selected materials according to research. Data were also obtained from thesis, regulations, Karimunjawa National Park Authority reports, and electronic mass media. So that 30 references are obtained that are relevant to this study. The research was conducted at the Karimunjawa National Park Agency, the Karimunjawa National Park manager.

\section{Result and discussion}

Karimunjawa National Park is the only marine conservation area in Central Java Province. This National Park is geographically located at coordinates $5^{\circ} 40^{\prime} 39^{\prime \prime}$ - 5 55'00" South Latitude and $110^{\circ} 05^{\prime} 57^{\prime \prime}-110^{\circ} 31^{\prime} 15^{\prime \prime}$ East Longitude and has various potentials as well as high biodiversity. To protect this potential, on April 9, 1986, Karimunjawa was designated as a Marine Nature Reserve based on the Decree of the Minister of Forestry No. 123/KptsII/1986. Then, on February 22, 1999, the Government changed its function to become a national park which was originated from Nature Reserve based on the Decree of the Minister of Forestry and Plantation No. 78/Kpts-II/1999 under the name Karimunjawa National Park. Karimunjawa National Park has an area of 111.625 hectares which is detailed in Table 1 [9].

Table 1. The Karimunjawa National Park Area.

\begin{tabular}{|c|c|c|}
\hline No & Area & $\begin{array}{c}\text { Area in } \\
\text { Hectare }\end{array}$ \\
\hline 1 & $\begin{array}{c}\text { Lowland tropical forest ecosystem area on the mainland of Karimunjawa } \\
\text { Island }\end{array}$ & $1.285,50$ \\
\hline 2 & The mangrove forest ecosystem area on the mainland of Kemujan Island & 222,20 \\
\hline 3 & $\begin{array}{c}\text { Water territory } \\
\text { On March 15, 2001, this area was designated as a nature conservation } \\
\text { area (KPA) based on the Decree of the Minister of Forestry No. 74/Kpts- } \\
\text { II/2001 }\end{array}$ & $110.117,30$ \\
\hline & Total Area in Hectare & $111.625,00$ \\
\hline
\end{tabular}

Karimunjawa National Park is a conservation area managed by the Karimunjawa National Park Hall under the Ministry of Environment and Forestry. Based on Article 5 of Law No. 5 of 1990, the management of the Karimunjawa National Park conservation area is carried out by providing protection for life support systems, carrying out preservation activities in the form of the diversity of various types of plants and animals, and their ecosystems, as well as making sustainable use of biological natural resources and their ecosystems [2].

\subsection{Anthropogenic threats}

The coral reef ecosystems in Karimujawa National Park have suffered damage due to natural factors and anthropogenic factors so that its area has decreased. Coral reef ecosystems are most sensitive to anthropogenic threats [10]. Anthropogenic threats that have a major impact on the damage to coral reefs in Karimunjawa National Park are tourist activities, fishermen activities, and vessel grounding. 


\subsubsection{Tourists activities}

One of the causes of damage to coral reefs is due the development of tourism in Karimunjawa. It can be said that the development of tourism in Karimunjawa National Park is not yet sustainable [11]. Other researchers also argue that tourism decreases the area of coral reefs, apart from natural factors $[6,12-15]$. The number of tourists in Karimunjawa National Park has increased yearly; from 2014 to 2016 it was recorded $79.123-118.301$ people [12]. Coral reefs are under pressure due to the large number of tourists visiting, coupled with the lack of knowledge about snorkelling information and less environmental awareness, so many corals are trampled and used as souvenirs [14]. Generally, people who visit Karimunjawa have not had snorkelling and diving basics. A tourist activity that has the potential to damage coral reefs is snorkelling. Snorkelling is a technique to see the beauty of the seabed with the help of a scuba diving mask, snorkel, and fin [16]. When snorkelling, tourists contact coral reefs such as sitting, stepping on, and others. The unscheduled anchoring of the boat anchors by tour boat owners also impacts coral reefs. So that what is often found at snorkelling spots is damage to coral colonies in the form of partial colony mortality, broken branches, and the eroded surface of coral colonies [16] [18]. In addition to that, the result of increased tourists has an impact on reducing the area of coral reefs on Menjangan Besar Island and Cemara Kecil Island, which can be seen in Table 2.

Table 2. The number of tourists and the area of coral reefs.

\begin{tabular}{|c|c|c|c|c|}
\hline \multirow{2}{*}{ Year } & \multirow{2}{*}{$\begin{array}{c}\text { Number of } \\
\text { tourists } \\
\text { (people) }\end{array}$} & $\begin{array}{c}\text { Tanjung Gelam } \\
\text { Island }\end{array}$ & $\begin{array}{c}\text { Menjangan } \\
\text { Besar Island }\end{array}$ & $\begin{array}{c}\text { Cemara Kecil } \\
\text { Island }\end{array}$ \\
\cline { 3 - 5 } & 118.301 & 6,12 & 7,92 & 7,84 \\
\hline 2016 & 122.876 & 6,92 & 7,57 & 7,66 \\
\hline 2017 & 137.835 & 6,97 & 7,36 & 7,42 \\
\hline
\end{tabular}

Source: Pribadi et al (2020)

\subsubsection{Fishers activities}

Another activity that can damage coral reefs is the activity of fishers who catch fish using potassium [19]. Fishers spread potassium where the fish congregate and around coral reefs. Fishers spray potassium into coral reefs because fish like to forage on coral reefs. The spread of potassium can change the colour of coral reefs, and slowly, coral reefs will die. Apart from the use of potassium, fishing activities that cause damage to coral reefs are the use of cantrang nets. This is because these nets can get caught in coral reefs and cause damage to coral reefs [20]. Fishing equipment such as potassium and cantrang nets are considered environmentally unfriendly tools that can damage coral reefs.

\subsubsection{Vessel grounding}

Barges docked in the Karimujawa archipelago for the weather was terrible, and they could not continue their journey, so they had to stop until the weather improved. Barges leaning in the Karimunjawa waters can damage coral reefs. This is evidenced by the number of damaged and dead coral reefs in the waters of several islands near the ship's berth. In Tengah Island, there was damage to coral reefs covering an area of 1.420,32 $\mathrm{m} 2$, and on Cilik Island, an area of $267,22 \mathrm{~m} 2$. The difference in the extent of damage was probably due to the type of fragile 
coral, the number of ships, and the time the barge ran aground [21]. In addition to that, on the island of Gosong Seloka, measurements were also carried out using the drone-groundtruth measurement technique, which resulted in the damage to coral reefs in Gosong Seloka covering an area of 184,45 $\mathrm{m} 2$ [22]. The damage to coral reefs was the result of the vessel grounding barge.

\subsection{Protection efforts of coral reefs}

Appendix II of the Decree of the State Minister for the Environment Number 4 of 2001 concerning Standard Criteria for Damage to Coral Reefs describes procedures for preventing, overcoming, and restoring coral reef damage. This regulation outlines several efforts that can be taken to prevent and overcome the damage to coral reef ecosystems. These are as follows: increasing public awareness and participation, community-based management, institutional development, research, monitoring and evaluation, and law enforcement. Meanwhile, the restoration of damaged coral reefs is carried out by zoning and rehabilitating coral reefs [4]. Based on the Decree of the Minister of Environment, efforts to protect coral reefs in Karimunjawa National Park are carried out by the Karimunjawa National Park Agency (BTNKJ) by carrying out the following socialization activities, marine waters patrol and law enforcement.

\subsubsection{Socialization}

Socialization is carried out to the community about the importance of the existence of coral reefs [23]. BTNKJ, together with HPI (the Association of Indonesian Tour Guides), conducts socialization to tour guides. The socialization is carried out by providing guidebooks. One of the materials provided is about how to guide tours in the waters. This socialization is a form of anticipation so that damage to coral reefs will not increase. Tour guides can guide visitors about what is allowed and not allowed when in the water, especially against coral reefs, so that visitors can understand the importance of coral reefs and keep coral reefs sustainable.

\subsubsection{Marine waters patrol}

Marine waters patrol activity is held to conserve coral reefs. It is carried out to visitors, fishermen, and large ships. Strategic allocation of resources by targeting patrols to locations and times where violations are most likely to occur is sensible and necessary [24].

a. Marine waters patrol to visitors;

This patrol is carried out when there are many visitors at Karimunjawa National Park. Forest Rangers, together with Forest Ecosystem Controller (PEH), patrolled visitors in the water. They monitor visitors and use loudspeakers from ships to give an appeal to tourists. The appeal is for visitors to be careful in snorkelling and diving activities. If the people are not used to doing these activities, you can accidentally step on the coral reef and cause the coral to break. In addition to that, visitors are also advised not to damage coral reefs and make their souvenirs, and visitors are expected to preserve coral reefs.

b. Marine waters patrol to fishermen;

Marine waters patrols of fishers are carried out by BTNKJ assisted by the Community of Forestry Partners (MMP). They patrol fishers local and fishers from outside Karimunjawa who use potassium and cantrang nets. Fishing using potassium is usually carried out by local fishermen, while fishing using cantrang nets is carried out by fishermen outside Karimunjawa. MMP is the Karimunjawa community, most of which members work as fishermen. When they are not patrolling or are working catching fish, if they see fishers using 
potassium or cantrang nets, they will immediately report the incident to BTNKJ for followup.

c. Marine waters patrol to large ships;

Marine waters patrols are also carried out to repel large ships including barges. When these large ships leaning in the waters of the Karimujawa islands, they can damage coral reefs. In joint patrol in 2018, nine large ships were found docked in the traditional fishing zone of the Legon Lele Resort and the Telaga Resort area. The captains and crews of the ship are given warnings and information to immediately leave the Karimunjawa National Park area because they have entered the waters of the Karimunjawa National Park Conservation Area which is a restricted area and is not a sea route and anchor point for large ships according to the 1998 Marine Map and Law on Conservation of Living Natural Resources and Their Ecosystems [25].

\subsubsection{Law enforcement}

Law enforcement is carried out to fishermen who use environmentally unfriendly equipment and large ships that experience the vessel grounding.

a. Law enforcement to fishermen who use non-environmentally friendly equipment;

Forest rangers take action against fishers who use non-environmentally friendly equipment in the form of potassium and cantrang nets by reporting them to the authorities. There were 10 cases of Law enforcement against fishers using potassium and cantrang nets from 2002 to 2015 (Figure 1). All of these cases were resolved through court proceedings with a sentence given in the form of imprisonment and a fine by the verdict from the court. After 2016, there were no more cases of fishermen using potassium and cantrang nets. This happened because routine patrols were carried out so that the community became more orderly. There was assistance from the MMP, who always reports fishermen who use nonenvironmentally friendly equipment when catching fish. In using equipment that is not environmentally friendly, even though it has not damaged coral reefs, it can be immediately reported and criminalized. criminalized.

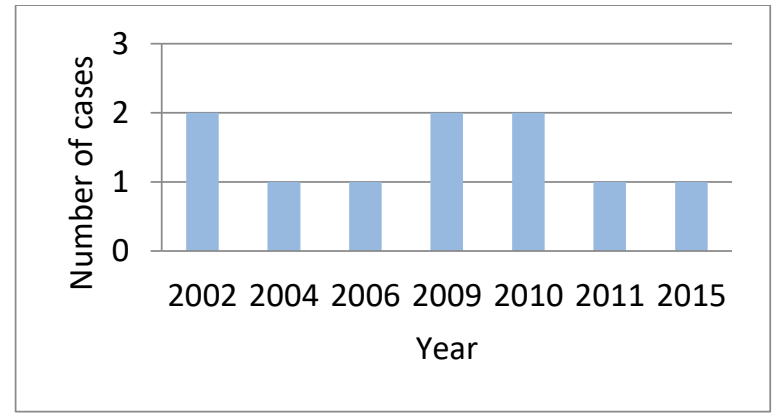

Fig. 1. Law enforcement to fishermen who use non-environmentally friendly equipment.

b. Law Enforcement to vessel grounding;

The first law enforcement of the vessel grounding which was in 2017 was completed in court. The suspect of destroying coral reefs is charged with criminal charges, but the resolution of law enforcement is considered not optimal and ineffective. So the vessel grounding case is then resolved through the settlement of the environmental disputes outside the court. Law enforcement of the vessel grounding through environmental dispute resolution outside the court is carried out by collaboration between BTNKJ with the Directorate of Environmental Disputes Handling (PSLH) of the Ministry of Environment and Forestry. The 
number of actions against the vessel grounding during 2017-2019 was 8 cases as shown in Figure 2.

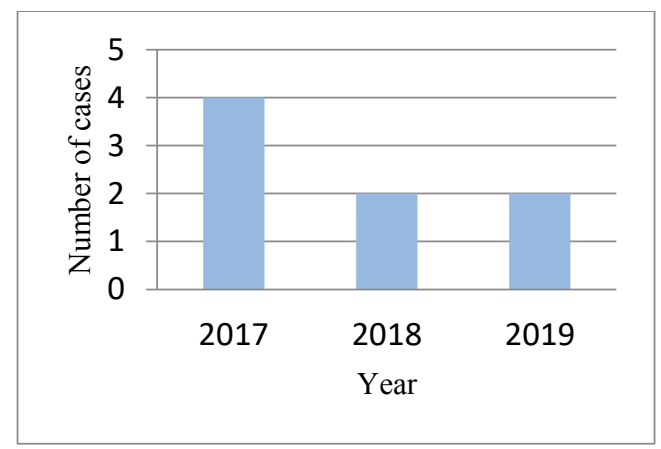

Fig. 2. Law enforcement to vessel grounding.

One vessel grounding case was resolved through the court, and there were 7 cases through environmental dispute resolution outside the court. The settlement of environmental disputes outside the court is carried out by paying compensation for damage to coral reefs. The stages in resolving vessel grounding through environmental dispute resolution outside the court are as follows:

- A ship that runs aground and damages coral reefs is detained along with its documents;

- BTNKJ conducts a ground check on the damage to the area of coral reefs and reports it to the Directorate of PSLH, Ministry of Environment and Forestry;

- The Directorate of PSLH together with the ship-owner company come to the scene of the incident and conduct a joint survey;

- Discussions are held to determine the extent of coral reefs between the Directorate of PSLH and the ship-owner companies;

- After there is a mutual agreement, the ship-owner company will pay the compensation documents;

Many vessel grounding cases are resolved through environmental dispute resolution outside the court because it is considered more effective, and compensation payments can be used to rehabilitate damaged coral reefs. The provision of criminal sanctions in environmental law enforcement is still more ineffective than administrative sanctions because administrative sanctions aim to restore environmental functions [26].

In Karimunjawa national park, the number of cases handled tends to decrease because patrols and law enforcement are routinely carried out. The number of law violations decreases with increasing law enforcement efforts [27]. US Environmental Protection initiated the Coral Reef Protection Plan in 2014 on Caribbean coral reefs [28]. In conserving coral reefs strategies to improve the status of coral reef ecosystems, with the highest priority placed on socialization, campaigns, and education, followed by law enforcement, selectivity in the use of fishing gear, rehabilitation of coral reef ecosystems, and restocking of coral reef fish [29]. The manager of the Karimunjawa National Park conducting socialization to provide understanding to the community in Karimunjawa about coral reef sustainability. Various efforts have been made to protect coral reefs, including local participation through fishermen, divers, NGOs, businessmen, and government officials committed to providing benefits to coral reefs and communities [30]. This is to preserve coral reefs.reefs. 


\section{Conclusion}

Based on the discussion above, it can be concluded that:

1. The biggest cause of damage to coral reefs in Karimunjawa National Park is the presence of unsustainable tourism activities, fishing activities using non-environmentally friendly equipment, and vessel grounding cases;

2. Activities to protect and safeguard coral reefs in Karimunjawa National Park have been carried out by the managers of Karimujawa National Park through socialization, patrol, and law enforcement activities;

3. Outreach and patrol activities are carried out as anticipatory or preventive activities so that damage to coral reefs does not increase, while law enforcement activities are a form of responsibility for the damage to coral reefs that have been caused.

\section{References}

[1] UU RI, Undang-undang no. 5 tahun 1990 tentang konservasi sumberdaya alam hayati dan ekosistemnya, (1990)

[2] N. A. E. Ariyani, Analisis faktor yang mempengaruhi implementasi kebijakan pengelolaan taman nasional Karimunjawa, (Universitas Diponegoro, 2018)

[3] E. Susanto et al., Laporan Pelaksanaan Kegiatan : Analisa Data Gangguan Keamanan Kawasan TNKJ 2008-2012, (Semarang, 2013)

[4] Menteri Negara Lingkungan Hidup, Keputusan menteri negara lingkungan hidup nomor 4 tahun 2001 tentang kriteria baku kerusakan terumbu karang, (2001)

[5] S. Setiawan, Terumbu Karang, (July, 2021), Retrieved from https://www.gurupendidikan.co.id/terumbu-karang/

[6] J. Irawan, B. Sasmito, A. Suprayogi, Pemetaan sebaran terumbu karang dengan metode algoritma lyzenga secara temporal menggunakan citra landsat 57 dan 8 (studi kasus : Pulau Karimunjawa), J. Geod. Undip, 6(2), 56-61 (2017)

[7] N. D. Uar, S. H. Murti, S. Hadisusanto, Kerusakan lingkungan akibat aktivitas manusia pada ekosistem terumbu karang, Maj. Geogr. Indones., 30(1), 88-95 (2016)

[8] E. V. Kennedy, J. Vercelloni, B. P. Neal, D. E. Bryant, A. Ganase, P. Gartrell, K. Brown, C. J. Kim, M. A. Hudatwi, A. Hadi, A. Prabowo, Coral reef community changes in Karimunjawa National Park, Indonesia: Assessing the efficacy of management in the face of local and global stressors, J. Mar. Sci. Eng., 8(10), 1-27 (2020)

[9] BTNKJ, Statistik Balai Taman Nasional Karimunjawa Tahun 2019, (2019)

[10] D. Adyasari, M. A. Pratama, N. A. Teguh, A. Sabdaningsih, M. A.

Kusumaningtyas, N. Dimova, Anthropogenic impact on Indonesian coastal water and ecosystems: Current status and future opportunities, Mar. Pollut. Bull., 171, 112689 (2021)

[11] S. N. Qodriyatun, Implementation of sustainable tourism development policies in Karimunjawa, Aspir. J. Masal. Sos., 9(2), 240-259 (2019)

[12] M. Farid, P. W. Purnomo, S. Supriharyono, Coral reef changes based on the number of tourism in Tanjung Gelam Karimunjawa Islands using satellite images landsat 8 OLI, Manag. Aquat. Resour. J., 7(1), 18-27 (2018)

[13] A. N. Laksono, Mussadun, Dampak aktivitas ekowisata di Pulau Karimunjawa berdasarkan persepsi masyarakat, Tek. Perenc. Wil. Kota, 3(2), 262-273 (2014) 
[14] F. Limbong, S. Soetomo, Dampak perkembangan pariwisata terhadap lingkungan Taman Nasional Karimunjawa, Ruang J. Perenc. Wil. dan Kota, 2(1), 351-360 (2014)

[15] A. H. Pribadi, S. Suryanti, C. A'in, The Impact of tourism activities on the status of coral reef cover and economic valuation in Karimunjawa Island, J. Maquares, 9(1), (2020)

[16] S. E. Priyanto, Dampak perkembangan pariwisata minat khusus snorkeling terhadap lingkungan: Kasus destinasi wisata Karimunjawa, J. Kepariwisataan, 10(3), 13-28 (2016)

[17] I. Biondi, Munasik, Koesoemadji, Kondisi terumbu karang pada lokasi wisata snorkeling di Kepulauan Karimunjawa, Jawa Tengah, J. Mar. Res., 194-201 (2014)

[18] D. S. Akhmad, P. W. Purnomo, S. Supriharyono, Potential damage to coral reef on snorkeling activities in Karimunjawa national park tourism destination, J. Ilmu dan Teknol. Kelaut. Trop., 10(2), 419-429 (2018)

[19] Pemerintah Kabupaten Jepara, (2016), Nelayan Karimunjwa Dukung Larangan Jaring Cantrang, Retrieved from https://jepara.go.id/2016/09/29/nelayankarimunjawa-dukung-larangan-jaring-cantrang/

[20] M. Idris, (2021) Apa Itu Cantrang dan Kenapa Dilarang di Era Susi Pudjiastuti?, Retrieved from https://money.kompas.com/read/2021/01/27/150625426/apa-itucantrang-dan-kenapa-dilarang-di-era-susi-pudjiastuti?page=all\#: :text=Cantrang adalah alat penangkap ikan,karena ukurannya masih relatif kecil

[21] M. Munasik, M. Helmi, R. M. Siringoringo, Suharsono, Pemetaan kerusakan terumbu karang akibat kandasnya kapal tongkang di taman nasional Karimunjawa, Jawa Tengah, J. Mar. Res., 9(3), 343-354 (2020)

[22] I. Yusidarta, N. D. Atmojo, Drone dan pengukuran kerusakan terumbu karang akibat vessel grounding di taman nasional Karimunjawa (studi kasus gosong seloka), Semin. Nas. Kelaut. XIII, 30-39 (2018)

[23] S. F. Tuhumury, J. Abrahamsz, D. Sahetapy, J. M. S. Tetelepta, J. Haulussy, Collaborative management response of coral reef at Biloro Village, District of Southern Buru, J. Trit., 17, 1-9 (2021)

[24] L. Thiault, D. Weekers, M. Curnock, N. Marshall, P. L. Pert, R. Beeden, M. Dyer, J. Claudet, Predicting poaching risk in marine protected areas for improved patrol efficiency, J. Environ. Manage., 254, 109808 (2020)

[25] Kristiawan, (2018), Patroli gabungan ditpolairut polda Jateng dan balai TN Karimunjawa, Retrieved from http://ksdae.menlhk.go.id/berita/4380/patroligabungan-ditpolaruid-polda-jateng-\&-balai-tn-karimunjawa.html

[26] S. M. T. Situmeang, Efektivitas sanksi pidana dalam penegakan hukum lingkungan, Res Nullius Law J., 1(2), 139-148 (2019)

[27] E. Gandiwa, I. M. A. Heitkönig, A. M. Lokhorst, H. H. T. Prins, C. Leeuwis, Illegal hunting and law enforcement during a period of economic decline in Zimbabwe: A case study of northern Gonarezhou National Park and adjacent areas, J. Nat. Conserv., 21(3), 133-142 (2013)

[28] J. F. Carriger, W. S. Fisher, C. T. LoBue, D. N. Cuevas-Miranda, Identifying and structuring objectives for a coral reef protection plan at the U.S. Environmental Protection Agency, J. Coast. Conserv., 22(2), 263-281 (2018)

[29] L. O. M. Yasir Haya, M. Fujii, Assessment of coral reef ecosystem status in the 
Pangkajene and Kepulauan Regency, Spermonde Archipelago, Indonesia, using the rapid appraisal for fisheries and the analytic hierarchy process, Mar. Policy, 118, 104028 (2020)

[30] C. Cortés-Useche, A. I. Muñiz-Castillo, J. Calle-Triviño, R. Yathiraj, J. E. AriasGonzález, Reef condition and protection of coral diversity and evolutionary history in the marine protected areas of Southeastern Dominican Republic, Reg. Stud.

Mar. Sci., 32, 100893 (2019) 